\title{
Descriptive study to assess the awareness of ill effects of consanguineous marriage on pregnancy, fetus and child in antenatal mothers
}

\author{
Dhipikasri Surendrakumar, Rajalekshmi Murugan*
}

Department of Obstetrics and Gynaecology, SIMATS, Chennai, Tamil Nadu, India

Received: 30 August 2020

Revised: 12 October 2020

Accepted: 15 October 2020

\section{*Correspondence:}

Dr. Rajalekshmi Murugan,

E-mail: dr.raji@live.in

Copyright: (C) the author(s), publisher and licensee Medip Academy. This is an open-access article distributed under the terms of the Creative Commons Attribution Non-Commercial License, which permits unrestricted non-commercial use, distribution, and reproduction in any medium, provided the original work is properly cited.

\begin{abstract}
Background: Consanguinity refers to marriage or a reproductive relationship between two closely related individuals. Consanguinity may significantly impact the occurrence of autosomal recessive conditions and congenital anomalies. The degree of relatedness between two individuals defines the proportion of genes shared between them. Hence this study was planned to assess the awareness level, the association between awareness level and education, association between awareness level of and socioeconomic class.

Methods: Direct interview through a self-structured questionnaire containing questions about demographic details, awareness of participants was conducted among $(\mathrm{n}=100)$ antenatal mothers attending SMC-OBG, OPD using convenient sampling. Knowledge of $\geq 50 \%$ is considered adequate. Data entry and analysis done using SPSS 16.0 software. Descriptive statistics were calculated for background variables like socio-demographic characteristics. $\mathrm{p}$ value less than 0.05 were considered to be statistically significant.

Results: $54 \%$ have an educational qualification above high school. $58 \%$ belonged to the lower socioeconomic strata. $67 \%$ had adequate knowledge. Out of the 26 people who have had consanguineous marriage, 30.8\% have 2' consanguinity, $69.2 \%$ have 3 ' consanguineous marriage. Participants having educational status above high school have 1.7 times more knowledge than lesser educational qualification. People of higher socioeconomic status have 3.2 times more knowledge than lower socioeconomic status. Association between knowledge with socioeconomic status is significant.

Conclusions: The target population has divergent attitudes towards consanguinity, though the awareness was decently high among many of them. Strategies to disseminate information in school programmes should be taken into consideration. Couples in consanguineous relationships can be identified, provided with information about their risk and, if needed referred for genetic counselling.
\end{abstract}

Keywords: Consanguinity, Consanguineous marriage, Antenatal mothers, Awareness, Education, Socioeconomic class, Congenital anomalies

\section{INTRODUCTION}

Consanguinity, derived from the Latin consanguineus (of common blood), is defined because the kinship of two individuals characterized by a shared common ancestor(s). It implies the inheritance of genes which are identical by descent, i.e., inherited from the common ancestor(s). ${ }^{1}$

Consanguinity is both a social and genetic concept. Generally, it refers to marriage or a reproductive relationship between two closely related individuals. The 
degree of relatedness between two individuals defines the proportion of genes shared between them. ${ }^{2}$

First degree consanguinity refers to marriage between brother and sister. Second degree consanguinity refers to marriage with maternal uncle and third degree consanguinity refers to marriage between first cousins. Consanguinity and inbreeding may significantly impact the occurrence and recurrence of autosomal-recessive conditions and congenital anomalies. ${ }^{3}$ A study among Pakistani population in Bradford, consanguinity was related to a doubling of risk for congenital abnormality. ${ }^{4}$

Rates of consanguinity are highly variable between and within countries, but the prevalence is highest in geographic area the center East, South Asia and among migrant communities in North America, Europe and Australia. ${ }^{5}$ Public understanding regarding the genetic risk of cousin marriage is usually low in countries with a high prevalence of consanguinity. At the identical time, an increasing interest expressed especially by young consanguineous couples in seeking genetic counselling was recently reported in these countries. ${ }^{6}$ In health care, cultural obstacles seem to exist between professionals and consanguineous couples, potentially resulting in lack of vigilance and unmet needs. ${ }^{7}$

Hence this study was planned to assess the awareness level of ill effects of consanguinity, to find the association between awareness level of ill effects of consanguinity and education and association between awareness level of ill effects of consanguinity and socioeconomic class in antenatal mothers attending OBG OPD of SMCH.

\section{METHODS}

\section{Study type}

Current study is a hospital based descriptive study.

\section{Study place and duration}

Saveetha medical college hospital between January 2019 to May 2019.

\section{Selection criteria}

Selection criterion for current study was all antenatal mothers willing to take part in the study.

\section{Sample size}

Assuming $50 \%$ as prevalence of good knowledge in Tamil Nadu, sample size calculation has been done using below mentioned.

$$
n=(Z \alpha 2 \times P \times Q) / L 2
$$

Where, $\mathrm{n}$ is minimum desired sample size, $\mathrm{Z} \alpha=1.96 \%$ (at $95 \% \mathrm{CI}), \mathrm{P}$ is prevalence of good knowledge $=50 \%, \mathrm{Q}$ is $100-50=50 \%, \mathrm{R}$ is absolute error $(10 \%)=(1.96 \times 1.96 \times$ $50 \times 50) / 100=9604 \sim 100$, therefore the sampling size, $\mathrm{n}=100$.

\section{Procedure}

After obtaining IRB approval and institutional ethical committee clearance, data collection was started and completed among 100 antenatal mothers attending Saveetha medical college, OBG, OPD using non probability sampling technique. A brief introduction was given to the participant regarding the purpose of the study after obtaining the informed consent. Care was also taken to ensure privacy and confidentiality of the interview. Relevant information was obtained by direct interview through a self-structured questionnaire after obtaining approval from the department. The questionnaire contains questions about the demographic details, awareness of the participants. Knowledge of $50 \%$ and more is considered adequate. Data entry and analysis was done using SPSS 16.0 for Windows software. Descriptive statistics were calculated for background variables like sociodemographic characteristics. $\mathrm{p}$ value less than 0.05 were considered to be statistically significant.

\section{RESULTS}

Out of the 100 participants in the study, $12 \%$ of people were less than 21 years, $74 \%$ of them were between 21 30 years and $14 \%$ of them were between $31-40$ years. $54 \%$ of the participants have an educational qualification above high school. Out of the total population $58 \%$ belonged to the lower socioeconomic strata (Table 2).

Out of the total population under study it was found that $67 \%$ of people had adequate knowledge of ill effects of consanguinity on pregnancy, fetus and child. The remaining $33 \%$ have inadequate knowledge (Figure 1). 26 of 100 people have had consanguineous marriages (Figure 2). Of the 26 people who have had consanguineous marriage, $30.8 \%$ have 2' consanguinity and $69.2 \%$ have 3 ' consanguineous marriage (Figure 3 ).

Results indicated that participants having educational status above high school have 1.7 times more knowledge on ill effects of consanguinity on pregnancy fetus and child than those with lesser educational qualification. People of higher socioeconomic status have 3.2 times more knowledge on ill effects of consanguinity than people of lower socioeconomic status (Table 3). Association between knowledge of the participant with their socioeconomic status was found to be significant (Table 3). There is no significant association between the awareness levels of the participant with their educational qualification (Table 3). 
Table 1: Data.

\begin{tabular}{|c|c|c|}
\hline Character assessed & Frequency & Percentage \\
\hline \multicolumn{3}{|c|}{ Are you aware that consanguinity causes ill effects in the fetus? } \\
\hline Yes & 86 & 86 \\
\hline No & 14 & 14 \\
\hline \multicolumn{3}{|c|}{ Are you aware that consanguinity can cause a high risk pregnancy? } \\
\hline Yes & 74 & 74 \\
\hline No & 26 & 26 \\
\hline \multicolumn{3}{|c|}{ Are you aware that consanguinity increases the risk of abortions during pregnancy? } \\
\hline Yes & 62 & 62 \\
\hline No & 38 & 38 \\
\hline \multicolumn{3}{|c|}{ Are you aware that consanguinity weakens the immunity of the child born against TB and hepatitis? } \\
\hline Yes & 44 & 44 \\
\hline No & 56 & 56 \\
\hline \multicolumn{3}{|c|}{ Are you aware that consanguinity increases risk of infant mortality? } \\
\hline Yes & 52 & 52 \\
\hline No & 48 & 48 \\
\hline \multicolumn{3}{|c|}{ Are you aware that consanguinity increases risk of autosomal recessive disorders like thalassemia in the child? } \\
\hline Yes & 44 & 44 \\
\hline No & 56 & 56 \\
\hline \multicolumn{3}{|c|}{ Are you aware that consanguinity can cause congenital defects like cleft lip and palate in the baby? } \\
\hline Yes & 58 & 58 \\
\hline No & 42 & 42 \\
\hline \multicolumn{3}{|c|}{ Are you aware that consanguinity can increase risk of blood cancers like Acute lymphocytic leukemia? } \\
\hline Yes & 38 & 38 \\
\hline No & 62 & 62 \\
\hline \multicolumn{3}{|c|}{ Are you aware that consanguinity may cause visual defects in the child? } \\
\hline Yes & 48 & 48 \\
\hline No & 52 & 52 \\
\hline \multicolumn{3}{|c|}{ Are you aware that the risk for pregnancy and fetus increases with closer the relation you marry? } \\
\hline Yes & 80 & 80 \\
\hline No & 20 & 20 \\
\hline \multicolumn{3}{|c|}{ Is yours a consanguineous marriage? } \\
\hline Yes & 26 & 26 \\
\hline No & 74 & 74 \\
\hline \multicolumn{3}{|c|}{ If yes what is the degree of consanguinity? } \\
\hline $1^{\prime}$ & 0 & 0 \\
\hline $2^{\prime}$ & 8 & 30.8 \\
\hline $3^{\prime}$ & 18 & 69.2 \\
\hline
\end{tabular}

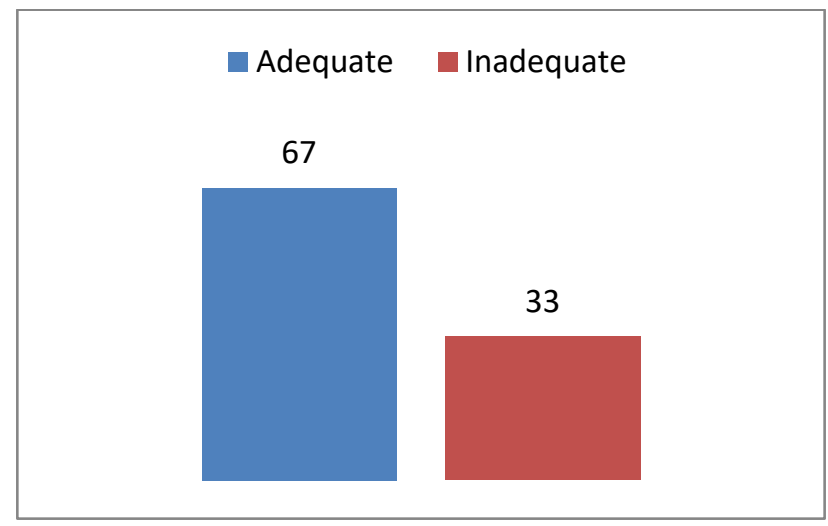

Figure 1: Distribution of population by awareness.

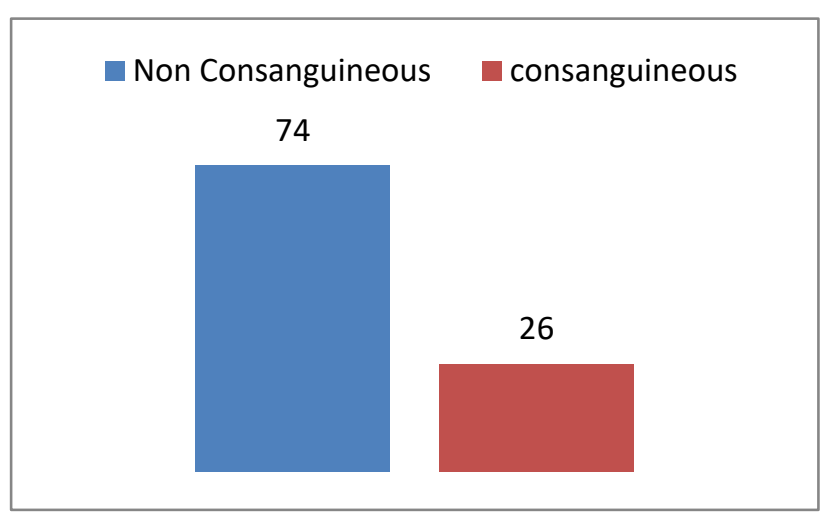

Figure 2: Distribution of population by practice. 
Table 2: Demographic details of the population under study.

\begin{tabular}{|lll|}
\hline Characteristics & Frequency & Percentage \\
\hline Age (in years) & & \\
\hline $18-20$ & 12 & 12 \\
\hline $21-30$ & 74 & 74 \\
\hline $31-40$ & 14 & 14 \\
\hline$>40$ & 0 & 0 \\
\hline Educational qualification & 6 & \\
\hline Illiterare & 12 & 12 \\
\hline Primary school & 10 & 10 \\
\hline Middle school & 18 & 18 \\
\hline High school & 8 & 8 \\
\hline Post high school/diploma & 32 & 32 \\
\hline Graduate/post graduate & 32 & 14 \\
\hline Profession and honors & 14 & \\
\hline Socio economic class & & 0 \\
\hline Upper & 0 & 42 \\
\hline Upper middle & 42 & 34 \\
\hline Lower middle & 34 & 13 \\
\hline Upper lower & 13 & 11 \\
\hline Lower & 11 & \\
\hline
\end{tabular}

Table 3: Awareness analysis in association with education and socioeconomic status.

\begin{tabular}{|c|c|c|}
\hline $\begin{array}{l}\text { Demographic } \\
\text { details }\end{array}$ & Frequency & $\begin{array}{l}\text { Adequate knowledge } \\
\text { N }(\%)\end{array}$ \\
\hline \multicolumn{3}{|l|}{ Education* } \\
\hline $\begin{array}{l}\text { Above high } \\
\text { school }\end{array}$ & 54 & $45(67)$ \\
\hline $\begin{array}{l}\text { high school } \\
\text { and below }\end{array}$ & 46 & $22(33)$ \\
\hline \multicolumn{3}{|c|}{ Socioeconomic status* } \\
\hline $\begin{array}{l}\text { upper and } \\
\text { upper middle }\end{array}$ & 42 & $47(70)$ \\
\hline $\begin{array}{l}\text { lower middle } \\
\text { and below } \\
\text { below }\end{array}$ & 58 & $20(30)$ \\
\hline \multicolumn{3}{|c|}{$\begin{array}{l}\text { Chi square and } p \text { values for education based analysis are } 2.9 \\
\text { and } 0.08 \text { respectively and for socioeconomic status based } \\
\text { analysis are } 12.8 \text { and } 0.0003 \text { respectively, } p<0.05 \text { is statistically } \\
\text { ignificant. }\end{array}$} \\
\hline
\end{tabular}

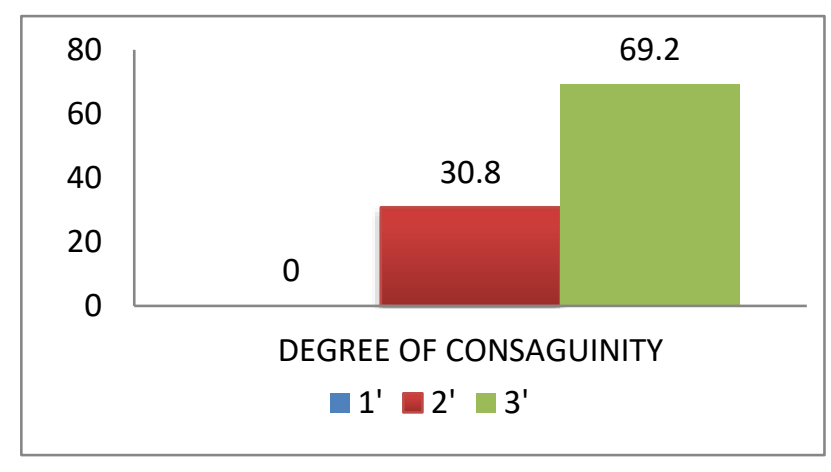

Figure 3: Awareness analysis in association with education and socioeconomic status.

\section{DISCUSSION}

Although most respondents appeared to have some awareness of the increased reproductive risk, one could question whether respondents have really understood the character of the chance, as illustrated by the dearth of data on specific defects. Limited genetic health literacy isn't unique for this group, but may be a more general phenomenon associated with the perceived difficulty of inheritance and genetics among the overall public in addition to health professionals as indicated by studies conducted by Teeuw et al. ${ }^{8}$

Awareness of health hazards associated with consanguineous marriages in this study was same same as those observations made by other studies where it ranged from $55.4 \%$ to $83.5 \% .^{9,10}$

Many of the participants were conscious of the very fact that the closer the blood bonds the higher the danger of anomalies within the child born. Many of them weren't alert to increased risk of fatal conditions like leukaemia during a child born out of consanguineous marriages, though they're tuned in to general risks like decreased immunity and congenital anomalies like congenital anomaly and congenital abnormality.

In our study knowledge of ill effects of consanguinity was found more in upper socioeconomic classes. Hence it may be stated that the socioeconomic status and education do play a crucial role in awareness, perception and subsequent safe practices like genetic counselling by the people.

\section{CONCLUSION}

In conclusion, the results show that the target population has various attitudes towards consanguinity, though the knowledge was decently high among many of them. Strategies to disseminate information in educational programmes should be taken into serious consideration. However, when targeting people already in an existing consanguineous relationship, perhaps the best opportunity lies within the practice of the health care professional. Here, these couples may be identified, supplied with information about their risk and, if needed referred for genetic counselling.

Funding: No funding sources

Conflict of interest: None declared

Ethical approval: The study was approved by the Institutional Ethics Committee

\section{REFERENCES}

1. Lefranc MP, Lefranc G. Consanguinity. In: Maloy S, Hughes K, editors. Brenner's Encyclopedia of Genetics. 2nd ed. San Diego: Academic Press; 2013: 158-162 
2. Koellner CM, Highsmith WE. The molecular basis of human diseases. In: Coleman W, Tsongalis G eds. Molecular Pathology. 2nd ed. United States: Academic press; 2018.

3. Holt RL, Trepanier A. Emery and Rimoin's principles and practice of medical genetics. 6th ed. Netherlends: Elsevier; 2013.

4. Hamamy H, Alwan S. Genomics and society. 1st ed. Netherlends: Elsevier; 2016.

5. Bittles AH, Black ML. Evolution in health and medicine Sackler colloquium: consanguinity, human evolution, and complex diseases. Proc Natl Acad Sci USA. 2010;107(Suppl 1):1779-86.

6. Sandridge AL, Takedinn J, Al-Kaabi E, Frances Y. Consanguinity in Qatar: knowledge, attitude and practice in a population born between 1946 and 1991. J Biosoc Sci. 2010;42:59-82.

7. Teeuw ME, Hagelaar A, Ten Kate LP, Cornel MC, Henneman L. Challenges in the care for consanguineous couples: an exploratory interview study among general practitioners and midwives. BMC Fam Pract. 2012;13:105.
8. Henneman L, Timmermans DR, Van der Wal G. Public experiences, knowledge and expectations about medical genetics and the use of genetic information. Community Genet. 2004;7:33-43.

9. Sedehi, M, Keshtkar, AA, Golalipour, MJ. The knowledge and the attitude of youth couples on/towards consanguineous marriages in the north of Iran. J Clin Diagn Res. 2012;6:1233-6.

10. Rahmani, SA, Aboualsoltani, F, Pourbarghi, M, Dolatkhah, H, Aghazade, MA. The frequency of consanguineous marriages and their effects on offspring in Tabriz City. Shiraz E-Med J. 2010;11:18-27.

Cite this article as: Surendrakumar D, Murugan R. Descriptive study to assess the awareness of ill effects of consanguineous marriage on pregnancy, fetus and child in antenatal mothers. Int J Reprod Contracept Obstet Gynecol 2020;9:4389-93. 